\title{
Analisis Bentuk Kesalahan dalam Mengarang Bahasa Jepang yang Dipengaruhi oleh Bahasa Pertama
}

\author{
Lispridona Diner \\ Universitas Negeri Semarang \\ lisjoost@yahoo.com
}

\begin{abstract}
Second language acquisition (SLA) for Indonesian students can be in the form of regional languages, Indonesian language, English as an international language or a foreign language. Foreign languages such as Mandarin, Korean and Japanese. The learning process of writing especially at the elementary level, students have difficulty in composing Japanese sentences. Based on observations, this happens because in the process of writing students are still influenced by the first language. Therefore, this study aims to determine the effect of first language in writing Japanese at the elementary level. The research method used in this study is a qualitative research method. The data of this research are in the form of students' essays in the Shokyuu Kohan sakubun course. And the data analysis technique used is the analysis of language errors. Based on the results and discussions, it can be concluded that writing Japanese essays is influenced by the first language, in this case the first language is Indonesian. Of the errors affected by the first language by $67 \%$ influenced by the sentence patterns of the first language and $33 \%$ influenced by the vocabulary of the first language.
\end{abstract}

Keywords: first language, Japanese, writing

\section{INTISARI}

Pemerolehan bahasa kedua (Second Language Acquisition/ SLA) bagi pembelajar Indonesia dapat berupa bahasa daerah, bahasa Indonesia, bahasa Inggris sebagai bahasa Internasional maupun bahasa asing. Bahasa asing seperti bahasa Mandarin, bahasa Korea dan bahasa Jepang. Proses pembelajaran mengarang khususnya tingkat dasar, mahasiswa mengalami kesulitan dalam menyusun kalimat bahasa Jepang. Berdasarkan pengamatan, hal ini terjadi dikarenakan dalam proses mengarang, mahasiswa masih dipengaruhi bahasa pertama. Oleh karena itu, penelitian ini bertujuan mengetahui pengaruh bahasa pertama dalam menulis bahasa Jepang tingkat dasar. Metode penelitian yang digunakan dalam penelitian ini adalah metode penelitian kualitatif. Data penelitian ini berupa hasil karangan mahasiswa dalam mata kuliah Sakubun Shokyuu kohan. Dan teknik analisis data yang digunakan yaitu analisis kesalahan berbahasa. Berdasarkan hasil dan pembahasan, maka dapat disimpulkan bahwa dalam menulis karangan bahasa Jepang dipengaruhi bahasa pertama dalam hal ini bahasa pertama adalah bahasa Indonesia. Dari kesalahan yang dipengaruhi bahasa pertama sebesar $67 \%$ dipengaruhi pola kalimat bahasa pertama dan $33 \%$ dipengaruhi kosakata bahasa pertama.

Kata kunci: bahasa pertama, bahasa Jepang, mengarang 


\section{PENDAHULUAN}

Pemerolehan bahasa kedua (Second Language Acquisition) bagi pembelajar Indonesia dapat berupa bahasa daerah, bahasa Indonesia, bahasa Inggris sebagai bahasa Internasional maupun bahasa asing. Bahasa asing di sini adalah bahasa selain bahasa ibu, seperti bahasa Mandarin, bahasa Korea, dan bahasa Jepang. Pemerolehan bahasa kedua dapat diperoleh melalui pendidikan formal, meskipun tak jarang dapat diperoleh juga dalam lingkungan keluarga atau lingkungan tempat tinggal. Chaer (2009:29), menulis bahwa teori behaviorisme yang menganggap bahwa faktor pemerolehan bahasa adalah faktor kebiasaan melalui faktor stimulus-response melahirkan beberapa metode pemerolehan bahasa dalam usahanya untuk memperoleh dan menguasai bahasa kedua. Adapun dalam teori interaksionisme berpandangan bahwa baik faktor psikologis maupun sosial, keduanya ikut mengambil peran dalam proses pemerolehan bahasa kedua (Gazhali, 2000:123)

Dalam pendidikan formal, pemerolehan bahasa asing sudah dimulai sejak Sekolah Dasar hingga Perguruan Tinggi. Jadi, dapat dikatakan pada era revolusi industry 4.0. Pembelajaran bahasa asing bukanlah sesuatu yang baru lagi. Di Indonesia, salah satu bahasa asing yang banyak diminati adalah bahasa Jepang.

Penyelenggaraan Pembelajaran bahasa Jepang pada pendidikan tingkat tinggi juga terdapat di Universitas Negeri Semarang (Unnes). Proses pembelajaran bahasa Jepang di Unnes dibagi sesuai dengan kemampuan berbahasa peserta didik. Kemampuan berbahasa yang dimaksud adalah kemampuan reseptif dan kemampuan produktif. Kemampuan reseptif yaitu kemampuan memahami bacaan (dokkai nouryoku) dan kemampuan mendengarkan (choukai nouryoku), sedangkan kemampuan produktif yaitu kemampuan berbicara (kaiwa noryoku) dan kemampuan menulis (sakubun nouryoku).

Pemerolehan bahasa Jepang pada pembelajar Indonesia di program studi pendidikan bahasa Jepang Unnes mengalami beberapa kendala. Kendala yang dihadapi antara lain adalah perbedaan bahasa Jepang tersebut dengan bahasa pertama (umumnya bahasa pertama mahasiswa adalah bahasa Indonesia) dan bahasa Jepang. Perbedaan tersebut dapat dilihat pada tabel 1 di bawah ini.

Tabel 1. Perbedaan Bahasa Indonesia dan Bahasa Jepang

\begin{tabular}{|l|l|}
\hline \multicolumn{1}{|c|}{ Bahasa Indonesia } & \multicolumn{1}{c|}{ Bahasa Jepang } \\
\hline Pola kalimat SPO & Pola kalimat SOP \\
\hline Huruf latin & Hiragana, katakana, kanji dan romaji \\
\hline Kata kerja dan kata sifat tidak mengalami perubahan & $\begin{array}{l}\text { Kata kerja dan kata sifat memiliki perubahan sesuai } \\
\text { keterangan waktu }\end{array}$ \\
\hline Sedikit kosakata yang sama memiliki arti berbeda & $\begin{array}{l}\text { Banyak kosakata yang sama memiliki arti yang } \\
\text { berbeda }\end{array}$ \\
\hline Tidak memiliki partikel & Memiliki banyak partikel disetiap kalimat \\
\hline
\end{tabular}

Dari tabel di atas diketahui bahwa perbedaan bahasa Indonesia dan bahasa Jepang dapat dikatakan memiliki perbedaan yang signifikan. Perbedaan ini meliputi pola kalimat, bentuk huruf, partikel, dan banyaknya kosakata yang mirip namun memiliki makna yang berbeda. Karena adanya perbedaan yang signifikan tersebut, pada saat proses pembelajaran bahasa Jepang, mahasiswa mengalami kesulitan. Kesulitan yang dialami oleh mahasiswa program studi pendidikan bahasa Jepang Unnes, khususnya pada kemampuan menulis. Kemampuan menulis bahasa Jepang tingkat dasar sebagian besar dipengaruhi bahasa pertama pembelajar. 
Melalui proses pembelajaran bahasa Jepang di program studi pendidikan bahasa Jepang Unnes, mahasiswa diharapkan memiliki kemampuan berbahasa yang seimbang. Dalam perkuliahan, setelah memperoleh materi berbahasa reseptif maka mahasiswa dapat menggunakan bahasa tersebut untuk memiliki kemampuan produktif. Oleh karena itu, perkuliahan yang berhubungan dengan kemampuan berbahasa reseptif (seperti bunpo, goi (pola kalimat) (kosakata), dokkai (membaca), kanji (menulis kanji) dan choukai (mendengarkan) diadakan pada hari pertama hingga ketiga setiap minggu, sedangkan kemampuan berbahasa produktif (seperti kaiwa (berbicara) dan sakubun (menulis) diadakan pada hari keempat dan kelima setiap minggu. Diharapkan setelah di awal minggu mahasiswa memperoleh materi kemampuan berbahasa reseptif, maka mahasiswa dapat menggunakan bahasa tersebut dan dapat dilihat kemampuan berbahasa produktif di perkuliahan paruh akhir minggu.

$$
\begin{aligned}
& \text { 書くとは自分の考えや意見、調べたこ } \\
& \text { と、やったことなどについて、相手に } \\
& \text { 説明し、理解してもらうために書くも } \\
& \text { のがあります。そして、形式や内容が } \\
& \text { 異なりますが、どちらも、「他の人に } \\
& \text { 何かを伝えるために書く」という点で、 } \\
& \text { コミュニケーションであるということ } \\
& \text { ができます。 }
\end{aligned}
$$

Kaku to wa jibun no kangae ya iken, shirabeta koto, yatta koto nado ni tsuite, aite ni rikai shi, rikaishite morau tameni kaku mono ga arimasu. Soshite, keishiki ya naiyou ga kotonarimasu ga, dochira mo [hoka no hito ni nani ka o tsutaeru tame ni kaku] to iu ten de, komyunike-shon dearu to iu koto ga dekimasu (Matsumoto, 2017, hal 3).

Menurut Matsumoto dalam kutipan di atas, menulis merupakan kegiatan komunikasi yang terjadi setelah sebuah pemikiran, pendapat, hasil pengamatan, pengalaman dan lain sebagainya dituangkan dalam tulisan dan dipahami oleh orang lain (lawan bicara/ partner dalam komunikasi). Pentingnya menulis juga diungkapkan oleh Nur Saadah (2017), dalam artikelnya di jurnal JAPANEDU. Menurut Nur Saadah, aktivitas menulis akan mendorong seseorang untuk mengembangkan daya inisiatif dan kreativitas, serta melatih keberanian untuk mengungkapkan pikiran secara tertulis.

Berdasarkan hasil observasi, proses pembelajaran menulis khususnya di tingkat dasar, mahasiswa mengalami kesulitan dalam menyusun kalimat bahasa Jepang. Berdasarkan pengamatan, hal ini terjadi disebabkan oleh faktor proses menulis mahasiswa yang masih dipengaruhi bahasa pertama. Oleh karena itu, penelitian ini bertujuan mengetahui pengaruh bahasa pertama dalam menulis karangan bahasa Jepang di tingkat dasar.

Pengaruh bahasa pertama terhadap bahasa kedua terjadi dalam menulis bahasa Jepang pada mata kuliah Sakubun Chuukyuu Zenhan. Mahasiswa sering melakukan transfer bahasa pertamanya dalam menulis bahasa Jepang, baik dalam peggunaan kosakata, pola kalimat ataupun ungkapan-ungkapan bahasa Jepang. Chaer (2009, 247) mengemukakan "transfer ini dapat terjadi pada semua tingkat kebahasaan: tata bunyi, tata bentuk kata, maupun tata kalimat". Mata kuliah Sakubun Chuukyuu Zenhan adalah mata kuliah berjenjang yang diperoleh oleh mahasiswa program studi pendidikan bahasa Jepang Unnes sejak semester empat sampai dengan semester enam. Sedangkan mata kuliah Sakubun Chuukyuu Zenhan diperoleh mahasiswa pada semester empat. Secara umum mata kuliah ini bertujuan, mahasiswa dapat menulis menggunakan bahasa Jepang dalam sebuah paragraf pendek sesuai tema yang telah ditentukan. Dan tujuan khusus dalam perkuliahan ini, mahasiswa dapat mengungkapkan budaya atau kebiasaan yang dilakukan di lingkungan tempat tinggalnya menggunakan pola kalimat, ungkapan, dan 
kosakata bahasa Jepang yang telah dipelajari.

\section{METODE PENELITIAN}

Metode penelitian yang digunakan dalam penelitian ini adalah metode penelitian kualitatif. Data penelitian ini berupa hasil karangan mahasiswa dalam mata kuliah Sakubun Shokyuuu Kohan. Data diambil pada mahasiswa semster 2 angkatan 2018/2019 semester genap pada tahun 2019. Subjek penelitian berjumlah 32 mahasiswa. Dan teknik analisis data yang digunakan yaitu analisis kesalahan berbahasa.

\section{HASIL DAN PEMBAHASAN}

Bentuk bentuk kesalahan kalimat akibat pengaruh bahasa pertama pada Hasil dan pembahasan ini akan dijelaskan berdasarkan data yang diperoleh dari hasil karangan mahasiswa. Data berupa daftar kesalahan kalimat bahasa Jepang yang muncul pada karangan mahasiswa yang menjadi objek penelitian, yaitu mahasiswa angkatan 2018 pada semester genap 2019.
Dari penjelasan tabel 1. dapat diketahui kalimat-kalimat yang dipengaruhi bahasa pertama. Dan berdasarkan analisis, maka diperoleh data penelitian dalam tabel 2.

Dari hasil pengumpulan data tersebut, sebagian besar kemampuan menulis mahasiswa dipengaruhi oleh bahasa pertama. Pengaruh bahasa pertama yang terlihat antara lain penggunaan pola kalimat bahasa pertama, dan juga kosakata dari bahasa pertama.

Dari hasil pengumpulan data tersebut, sebagian besar kemampuan menulis mahasiswa yang dipengaruhi bahasa pertama adalah dipengaruhi penggunaan pola kalimat bahasa pertama. Dari 12 data kalimat yang dipengaruhi pola kalimat bahasa pertama $67 \%$, dan dipengaruhi kosakata bahasa pertama sebesar 33\%. Pengaruh bahasa pertama dalam menulis bahasa Jepang terjadi pada empat tema yaitu tema "Mengenalkan Makanan", "Mengenalkan Tempat Wisata", "Kelebihan dan kekurangan Internet", dan "Pendidikan di Indonesia".

Tabel 2. Data Penelitian Berupa Kalimat yang Dipengaruhi Bahasa Pertama

\begin{tabular}{|c|c|c|}
\hline Tema & Data & $\begin{array}{c}\text { Pengaruh bahasa } \\
\text { pertama }\end{array}$ \\
\hline \multirow{3}{*}{$\begin{array}{l}\text { Mengenalkan } \\
\text { makanan }\end{array}$} & 1 私は母に料理を作られた。 & $\begin{array}{l}\text { Pola kalimat bahasa } \\
\text { Indonesia }\end{array}$ \\
\hline & ${ }^{2}$ Selat solo は体によくて、ビタミンを妊娠しています。 & Kosakata \\
\hline & $\begin{array}{l}{ }^{3} \text { Batang へ来たら、ぜひセゴメゴノという料理の Batang を } \\
\text { 食べてください。 }\end{array}$ & Pola kalimat \\
\hline \multirow{4}{*}{$\begin{array}{l}\text { Mengenalkan } \\
\text { tempat wisata. }\end{array}$} & 4 買った旅行のガイドブックは分かるのが簡単です。 & Kosakata \\
\hline & 5 人たちは観光マップがもう分かることができる。 & Kosakata \\
\hline & 6私は私の父と行ったことがあります。 & Kosakata \\
\hline & 77友達はダイビングをもうしたことがりますか。 & Pola kalimat \\
\hline \multirow{3}{*}{$\begin{array}{l}\text { Kelebihan dan } \\
\text { kekurangan } \\
\text { internet }\end{array}$} & 8 高校の時、インタネットを先生に教えられた。 & Pola kalimat \\
\hline & $\begin{array}{l}9 \text { インタネットの一つの問題は例えば、インタネットを通じ } \\
\text { て、データやプログラムなどをとられることができる。 }\end{array}$ & Pola kalimat \\
\hline & $\begin{array}{l}10 \text { 私のフェイスブックは人に開かれましたから、フェイスブ } \\
\text { ックを突然見られなくなりました。 }\end{array}$ & $\begin{array}{l}\text { Partikel dan Pola } \\
\text { kalimat }\end{array}$ \\
\hline \multirow{2}{*}{$\begin{array}{l}\text { Pendidikan di } \\
\text { Indonesia }\end{array}$} & 11 インドネシアの学校に毎年校長の会議があります。 & $\begin{array}{l}\text { Partikel dan pola } \\
\text { kalimat }\end{array}$ \\
\hline & ${ }^{12}$ インドネシアと日本の教育制度は日本のほうがいいです。 & Pola kalimat \\
\hline
\end{tabular}

Dalam perkuliahan Sakubun Chuukyuu Zenhan mahasiswa menulis karangan dalam enam tema yaitu mengenalkan makanan, mengenalkan tempat wisata, 
kelebihan dan kekurangan internet, membuat angket, pendidikan di Indonesia dan gender. Pembahasan tentang data yang dipengaruhi bahasa pertama akan dibahas sebagai berikut.

\section{Pengaruh Pola Kalimat Bahasa Pertama} Data 1

私は母に料理を作られたです。

Watashi wa haha ni ryouri o tsukuraretadesu.

Saya dibuatkan ibu masakan.

Mahasiswa menulis kalimat tersebut karena pengaruh bahasa Indonesia yaitu pada pola kalimat pasif, dalam bahasa Indonesia untuk mengungkapkan kalimat "dibuatkan" menggunakan kalimat pasif. Kalimat "saya dibuatkan ibu masakan", dalam bahasa Jepang pola kalimat tersebut adalah pola kalimat "yarimorau/ jujuhyougen" yaitu kalimat yang mengandung unsur jasa, dimana saya menerima jasa dari ibu berupa dibuatkan masakan. Pola kalimat yang digunakan yaitu 〜てもらう(-te morau) Jadi kalimat yang benar adalah “私は母に料理を作って もらいました” (Watashi wa haha hi ryouri o tsukutte moraimashita).

\section{Data 3}

Batang へ来たら、ぜひセゴメゴノと いう料理の Batang を食べてくださ い。

Batang e kitara, zehi Sego Megono to iu ryouri No. Batang o tabete kudasai.

Kalau datang ke Batang silakan makan masakan Batang yang disebut Sego Megono Batang.

Pada kalimat ini, mahasiswa melakukan kesalahan karena dipengaruhi aturan tata bahasa Indonesia dalam menjelaskan sesuatu yaitu "menerangkan" dan "diterangkan". Dalam bahasa Indonesia terdapat hukum DM, atau "diterangkan menerangkan", misalnya untuk "Sepatu Baru", maka yang "diterangkan" adalah "sepatu" dan yang menerangkan adalah "baru". Sedangkan dalam bahasa Jepang, polanya terbalik, yaitu menjadi "menerangkan diterangkan". Pada "Nasi Megono Batang", mahasiswa menulis “料理 $の$ Batang” (ryouri no Batang) yang benar adalah "Batang の料理” (Batang no ryouri). Jadi, kalimat yang benar adalah "Batang へ来た ら、ぜひセゴメゴノという Batang の料理 を食べてください” (Batang e kitara, zehi Sego Megono to iu Batang no ryouri o tabete kudasai).

Data 7

*友達はダイビングをもうしたこと がりますか。(kalimat salah)

Tomodachi wa daibingu o mou shita koto ga arimasuka.

Apakah teman-teman pernah melakukan diving.

Berdasarkan pengamatan pada hasil karangan, rata-rata mahasiswa melakukan kesalahan karena dipengaruhi bahasa pertama, dalam mengungkapkan pengalaman bahasa Indonesia menggunakan kata "pernah atau sudah pernah". Dalam kalimat di atas, mahasiswa menambahkan kata “もう” (mou) berarti “sudah” dan menam-bahkan pola “〜ことがあります” (koto ga arimasu). Sedangkan dalam tata bahasa Jepang menggunakan pola “〜こと があります” (koto ga arimasu) tanpa menggunakan “もう” (mou). Jadi kalimat yang benar adalah “友達はダイビングをし たことがりますか” (Tomodachi wa daibingu o shita koto ga arimasuka).

Data 8

高校の時、インターネットを先生に 教えられた。

Koukou no toki, intanetto o sensei ni oshierareta.

Pada waktu SMA, saya diajarkan guru internet.

Pada kalimat di atas mahasiswa menulis kalimat tersebut karena pengaruh bahasa Indonesia yaitu pada pola kalimat 
pasif, dalam bahasa Indonesia untuk mengungkapkan kalimat "diajarkan" menggunakan kalimat pasif. Kalimat "Pada waktu SMA, saya diajarkan guru internet". Seharusnya dalam bahasa Jepang pola kalimat tersebut merupakan pola kalimat "yarimorau/jujuhyougen". Pola kalimat Jujuhyougen adalah pola kalimat yang mengandung unsur jasa, seperti pada penjelasan data 1, "Saya menerima jasa dari ibu berupa dibuatkan masakan".

Pola kalimat yang digunakan pada kalimat ini yaitu “〜てもらう” (-te morau). Jadi kalimat yang benar seharusnya adalah “高校の時、インターネットを先生に教え てもらった” (Koukou no toki, intaanetto o sensei ini oshiete moratta).

Data 9

$$
\begin{aligned}
& \text { インターネットの一つの問題は例え } \\
& \text { ば、インターネットを通じて、デー } \\
& \text { タやプログラムなどをとられること } \\
& \text { ができる。 }
\end{aligned}
$$

Intaanetto no hitotsu no mondai wa tatoeba, intanetto o tsuujite, deeta ya puroguramu nado o torareru koto ga dekiru.

Salah satu masalah internet,' seperti dapat diambil/dicuri data melalui internet.

Pada data 9, mahasiswa melakukan kesalahan karena pada kalimat di atas dipengaruhi bahasa Indonesia yaitu saat mengungkapkan bentuk pasif dapat diikuti dengan kata "dapat" seperti "dapat dicuri". Sedangkan dalam bahasa Jepang, menggunakan pola kalimat pasif tidak dapat digabung pola kalimat potensial/kanoudoushi. Jadi kalimat yang benar seharusnya adalah “インターネット の一つの問題は例えば、インターネットを 通じて、データやプログラムなどをとられ ることです” (Intaanetto no hitotsu no mondai wa tatoeba, intaanetto o tsuujite, deeta ya puroguramu nado o torareru koto desu).
Data 10

$$
\begin{aligned}
& \text { 私のフェイスブックは人に開かれま } \\
& \text { したから、フェイスブックを突然見 } \\
& \text { られなくなりました。 } \\
& \text { Watashi no fesubukku wa hito ni } \\
& \text { hirakaremashita kara, fesubukku o } \\
& \text { totsuzen mirarenaku narimashita. } \\
& \text { Tiba-tiba tidak bisa melihat } \\
& \text { faccebook, karena facebook saya } \\
& \text { dibuka orang. }
\end{aligned}
$$

Di sini mahasiswa melakukan kesalahan dengan menerapkan aturan DM, atau pola kalimat "diterangkan menerangkan pada kalimat”“私のフェイスブック” (watashi no fesubukku). Dalam bahasa Jepang pola kalimat pasif “〜は〜に〜を 受身形” (-wa-ni-o-ukemikei) atau “〜は〜を 受身形” (-wa-o-ukemikei). Jadi kalimat yang benar adalah “私は人にフェイスブッ クを開かれましたから、フェイスブックを 突然見られなくなりました” (Watashi wa hito ni fesubukku o hirakaremashita kara, fesubukku o totsuzen mirarenaku narimashita).

Data 11

インドネシアの学校に毎年校長の会 議があります。

Indoneshia no gakkou ni maitoshi kouchou no kaigi ga arimasu.

Di sekolah Indonesia setiap tahun ada rapat kepala sekolah.

Pada data kalimat di atas, mahasiswa melakukan kesalahan karena dipengaruhi bahasa Indonesia yaitu pola penggunaan kata depan "di". Pada Bahasa Indonesia, kata depan "di" dipakai untuk menunjukkan tempat. Sedangkan dalam bahasa Jepang letak suatu benda/ posisi disebut dengan menggunakan partikel yaitu partikel “に (ni) atau で (de)”. Fungsi partikel $に$ bermacam-macam salah satunya menunjukkan tempat keberadaan suatu barang dan fungsi partikel "で" $(d e)$ adalah 
menunjukan suatu tempat dilaksanakannya sebuah kegiatan. Kalimat kalimat di atas salah karena menggunakan partikel “に” (ni) pada bagian yang seharusnya menunjukkan dilaksanakannya sebuah kegiatan yaitu "rapat kepala sekolah". Jadi kalimat yang benar adalah “インドネシア の学校で毎年校長の会議があります” (Indoneshia no gakkou de maitoshi kouchou no kaigi ga arimasu).

Data 12

$$
\begin{aligned}
& \text { インドネシアと日本の教育制度は日 } \\
& \text { 本のほうがいいです。 }
\end{aligned}
$$

Indoneshia to nihon no kyouiku seido wa nihon no hou ga ii desu.

Sistem pendidikan di Jepang lebih baik daripada di Indonesia.

Pada kalimat di atas mahasiswa melakukan kesalahan karena kalimatnya dipengaruhi bahasa Indonesia yaitu pola kalimat mengungkapkan perbandingan. Dalam bahasa Indonesia, menyatakan perbandingan bisa diungkapkan dengan kata "dan" (partikel “と” (to) atau "daripada". Sedangkan dalam bahasa Jepang diungkapkan dengan pola kalimat “〜は〜より〜のほうが〜” (...wa ...yori ...no houga...). Sedangkan untuk menyatakan pendapat menggunakan pola kalimat “〜いいと思います” (ii to omoimasu). Jadi kalimat yang benar adalah “教育制度はインドネシアより日本のほう がいいと思います” (Kyouiku seido wa Indoneshia yori nihon no houga ii to omoimasu).

\section{Pengaruh Kosakata Bahasa Pertama}

Data 2

Selat Solo は体によくて、ビタミン を妊娠しています。

Selat Solo wa karada ni yokute, bitamin o ninshin shiteimasu.

Selat solo mengandung vitamin dan baik untuk tubuh.

Di sini mahasiswa melakukan kesalahan penyusunan kalimat oleh karena pengaruh kosakata bahasa Indonesia. Pada kalimat data 2 ini digunakan kata “妊娠” (ninshin) yang berarti "mengandung" yang digunakan untuk "mengandung anak/hamil". Dalam bahasa Indonesia kata "mengandung " dapat digunakan dalam kalimat seperti "mengandung vitamin" dan "mengandung anak" (hamil). Sedangkan dalam bahasa Jepang, "mengandung vitamin”“ビタミンを含みます” (bitamin o fukumimasu), dan "mengandung anak" “妊 娠しています” (ninshin shiteimasu). Jadi, kalimat yang benar adalah "Selat solo は体 に良くて、ビタミンを含みます” (Selat Solo wa karada ni yokute, bitamin o fukumimasu).

Data 4

買った旅行のガイドブックは分かる のが簡単です。

Katta ryokou no gaidobukku wa wakaru no ga kantan desu.

Buku panduan wisata yang dibeli mudah dipahami.

Pada data 4 mahasiswa melakukan kesalahan karena kalimatnya dipengaruhi kosakata bahasa Indonesia. Dalam bahasa Indonesia "mudah dipahami" tidak menggunakan pola kalimat khusus. Mahasiswa menggunakan kata “分かる” (wakaru )yaitu "paham” dan “簡単” (kantan) yang berarti "mudah". Sedangkan dalam bahasa Jepang "mudah dipahami" memiliki pola khusus yaitu “〜やすい” (yasui), menjadi “分かりやすい” (wakariyasui). Jadi, kalimat yang benar adalah “買った旅行のガイドブックは分か りやすいです” (Katta ryokou no gaidobuku wa wakariyasui desu).

Data 5

人たちは観光マップがもう分かるこ とができる。

Hitotachi wa kankou mappu gam o wakaru koto ga dekiru.

Orang-orang sudah dapat memahami peta wisata. 
Pada kalimat ini, mahasiswa melakukan kesalahan dengan menulis kalimat yang dipengaruhi bahasa Indonesia. Dapat dilihat pada kosakata “もう分かるこ とができる” (mou wakaru koto ga dekiru) yang secara harfiah berarti, "sudah dapat". Kata "sudah" menggunakan “もう” ( $\mathrm{mou})$, kata "dapat" menggunakan pola “〜ことが できる” (-koto ga dekiru). Sedangkan dalam bahasa Jepang kata “分かる” (wakaru) termasuk dalam kata kerja 可能動 詞 (kanoudoushi) (kata kerja yang menunjukkan kemampuan), oleh karena itu tidak perlu ditambahkan “〜ことができる” (-koto ga dekiru) di belakang “分かる” (wakaru). Jadi kalimat yang tepat seharusnya adalah “人たちは観光マップが もう分かる” (Hitotachi wa kankou mappu ga mou wakaru).

Data 6

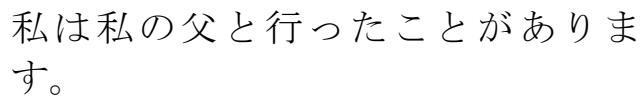
す。

Watashi wa watashi no chichi to itta koto ga arimasu.

Saya pernah pergi dengan ayah saya.

Di sini mahasiswa melakukan kesalahan karena dipengaruhi bahasa pertama, kata “ayah saya” menjadi “私の 父” (watashi no chichi). Sedangkan dalam bahasa Jepang mengungkapkan ayah sendiri dan ayah orang lain berbeda, kosakata “父” (chichi) sudah menunjukan "ayah untuk diri sendiri", "ayah orang lain" yaitu “お父さん” (otousan). Jadi kalimat yang benar adalah “私は父と行ったことが あります” (Watashi wa chichi to itta koto ga arimasu).

Dari hasil dan pembahasan di atas, dapat dilihat temuan berupa 12 data kesalahan penyusunan kalimat dalam 4 tema karangan yang disusun siswa pada mata kuliah Sakubun Chuukyuu Zenhan di tahun 2019. Dari hasil analisis dapat diketahui bahwa kesalahan yang tampak merupakan kesalahan yang dilakukan mahasiswa di tingkat awal karena dipengaruhi bahasa pertama.

\section{KESIMPULAN}

Berdasarkan hasil dan pembahasan dapat disimpulkan bahwa mahasiswa yang menjadi subjek penelitian, yaitu mahasiswa tingkat dasar di Unnes, ketika menulis karangan bahasa Jepang masih terpengaruh bahasa pertamanya yaitu bahasa Indonesia. Dari kesalahan yang ditemukan, terdapat prosentase sebesar $67 \%$ kalimat yang dipengaruhi pola kalimat bahasa pertama dan 33\% dipengaruhi kosakata bahasa pertama.

Melalui penelitian ini dapat diketahui masih banyak kesalahan mahasiswa dalam menulis bahasa Jepang yang dipengaruhi oleh bahasa pertama, maka perlu teknik mengajar yang tepat dalam mengajar menulis bahasa Jepang untuk mengurangi pengaruhi bahasa pertama ini. Selain itu, teknik mengajar yang tepat dalam pembelajaran pola kalimat dan kosakata juga diperlukan agar dalam aplikasi kalimat dalam menulis bahasa Jepang tidak mudah dipengaruhi bahasa pertama.

\section{DAFTAR PUSTAKA}

Chaer, Abdul. (2009). Psikolinguistik Kajian Teoritik. Jakarta: Rineka Cipta

Ghazali, Syukur. (2000). Pemerolehan dan Pengajaran Bahasa Kedua. Jakarta: Dikti Depdiknas.

Kokusai Kouryuu Kikin. (2009). JF Nihon Kyouiku Sutandaado Shikouhan.

Luo, Zeyu. (2014). Mokuhyou Gengo Kara Bogo he No. Gyakkou Ten'i No. Jitsurei- Nihongo Kara Chuugokugo he. Shizuoka Bunka Geijutsu Daigaku Kenkyuu. Vol 15. 2004.

Matsumoto, Isao. (2017). Kaku Koto to Kangaeru. Japan: Kokusai Kouryuu Kikin.

Nur Saadah, F.A. (2017). Model Materi Ajar Menulis Deskriptif dalam Bahasa Jepang berbasis Pendekatan Proses. Japanedu, 2(2), 114-131. 